\title{
The role of DFMEA in the integration between product development and quality engineering: cases in large companies
}

\author{
Fernanda Campos Bueno, José Carlos de Toledo, Sérgio Luis da Silva \\ Departamento de Engenharia de Producc̃ao, Universidade Federal de São Carlos - UFSCar \\ e-mails: fercbueno.15@gmail.com; toledo@dep.ufscar.br; sergio@ufscar.br
}

\begin{abstract}
The increasing trend of product recalls is due to quality implications in the early stages of the Product Development Process (PDP) and could be prevented through preventive measures from the quality management system such as Design Failure Modes Analysis and Effects (DFMEA), one of the main tools of Quality Engineering. Besides the quality of products, functional integration is also considered one of the ways in which companies respond to competitive pressures. Thus, in the search for best practices to organize and manage product development, this article aims to examine the role of DFMEA in the context of functional integration between Product Development (PD) and Quality Engineering (QE) through case studies in two Brazilian industrial companies. The companies differ in the physical proximity between these departments, where one case PD and QE are co-located and the other are located in different cities and states. The results point that the use of integration practices such as Information and Communication Technologies (ICTs) and co-location during a DFMEA and despite the advancement of ICTs, co-location has indicated that it is a relevant mechanism to improve problem solving, due to the detail of the information and dynamism of the discussion meetings of failures and solutions. In addition, companies link the compensation system of employees to the failure rates of the new product in the market and the costs of non-quality boosting communication and collaboration between teams. In one of the cases, the integration is also facilitated by the PD and QE activities and the DFMEA reports are reported to the same manager.
\end{abstract}

Keywords: product development, quality engineering, functional integration, DFMEA.

\section{Introduction}

Product quality is a feature that distinguishes a company from its competitors and many recalls, could be prevented through preventive measures from the quality management system (HUO; ZHAO; LAI, 2014). The introduction of quality assurance practices during product development, such as verification and validation activities, increases the likelihood of development to be successful (ERIKSSON; MOTTE, 2013; KOCH et al., 2013; BADIRU, 2014).

The integration between the Quality and the Product Development (PD) has the ability to boost members to assume responsibility for the quality encouraging them to work in cooperation with the same quality criteria (SHAO et al., 2006; HUO; ZHAO; LAI, 2014). Koch et al. (2013) and Kurniati, Yeh and Lin (2015) believe that quality management during the development phase occurs through interdependent activities between Quality and PD as tests and inspections. For Chan, Ip and Zhang (2012) and Jiang et al. (2012) the reduction of quality problems must be established through the implementation of methods such as the Failure Mode and Effect Analysis (FMEA) from the early stages of product development.
The FMEA is considered a mechanism that can be used to coordinate development groups that are scattered in organizations (GUERRERO; BRADLEY, 2012). Although FMEA can be an effective tool for reliability and maintenance, its results are often limited by its susceptibility to human mistakes as it is performed by a group of people, that is, a multifunctional team. The formation of teams to carry out the analysis of failures can present difficulties in the interactions among the members, inefficient leadership and lack of collaboration (BANGHART; BABSKI-REEVES; BIAN, 2016) due to inconsistent and discrepant information exchanges prejudicing the analyzes (CHAO; ISHII, 2007; GUERRERO; BRADLEY, 2012; CABANES et al., 2016; RENU et al., 2016) once the quantity and quality of information used during a FMEA influences its quality (BANGHART; BABSKI-REEVES; BIAN, 2016).

From the organizational point of view, the physical proximity between departments, that is, colocation can increase communication between team members (GRIFFIN; HAUSER, 1996; LEENDERS; WIERENGA, 2002; GRAY; SIEMSEN; VASUDEVA, 2015) e to boost the integration 
between them, which can lead to better problem solving (LEENDERS; WIERENGA, 2002; GRAY; SIEMSEN; VASUDEVA, 2015). On the other hand, the use of Information Technology (IT) improves and accelerates the sending and receiving of information since it makes the product development team available to collaborate and coordinate from anywhere at any time (BANKER; BARDHAN; ASDEMIR, 2006; KWON et al., 2006; TSENG; ABDALLA; SHEHAB, 2006; REID et al., 2016).

However, there are no studies that identify and analyze practices that can contribute to the integration between Product Development and Quality Engineering (QE), through the implementation of DFMEA. As suggested by Guerrero and Bradley (2012) and Banghart, Babski-reeves and Bian (2016), the FMEAs are subject to bias and it is necessary to investigate how it is carried out, identifying the strategies according to the perspectives of the integration to the realization of the same, as well as the problems and challenges faced.

Given this context, it is necessary to contribute to this field of knowledge through the identification of difficulties and good practices of this tool to overcome the limitations, especially in the early stages of development (DFMEA) verifying by means of case studies in two Brazilian industrial companies from different sectors what integration practices are adopted, which main criterion of choice was based in the different localization arrangements between these areas, that is, the co-location between PD departments and Quality Engineering and the development of more complex products that require quality certification.

The article was divided as follows: the next topic presents a brief theoretical reference. Next, the employed search method is exposed. Subsequently, the case study is presented and analyzed. Finally, the final considerations, as well as the limitations of the research and the suggestions for future work are presented.

\section{Theoretical background}

\subsection{Interfunctional Integration}

Interfunctional integration has been described by academics using a wide range of terms: integration, coordination, collaboration, cooperation, teamwork, unity of effort, connectivity, and alignment (CHEN et al., 2009) and can be defined from three dimensions: one defines integration as an interaction process; another defines integration as a process of collaboration; and another as a combination of processes of interaction and collaboration (KAHN, 1996).

The interaction involves activities coordinated formally based on communication activities and information sharing between departments, such as holding meetings, teleconferences, informal conversations, emails, reports.
Collaboration is informal processes of integration and consists of the development of joint activities involving affective aspects, that is, something that depends on the good will and willingness to work together, mutual trust, understanding and sharing of the same vision, resources and information, aiming the achievement of common objectives (KAHN, 1996).

Similar to Kahn's (1996) definition, Chen et al. (2009) state that interfunctional integration can be divided into two components. The first refers to shared and understood information, that is, information should not only be shared but must be carried out frequently and understood by those involved. The second component refers to "aligned decisions" that involve the functions, which must take into account the capacities and objectives of each one of them. Dietrich et al. (2010) define collaboration as a process in which people, or organizations, work together with common goals to share knowledge, learn, and build consensus. The combination of these two forms of integration - interaction and collaboration - implies that there should be information sharing and involvement between departments (KAHN, 1996; SONG, 1998; OLSON et al., 2001; PAGELL, 2004).

The way the company organizes itself to enable interfunctional integration is called "integration mechanisms" and is often used as synonyms for practices. They are: co-location and physical closeness, job rotation, informal social systems, organizational structure, incentives and rewards, and formal management of the integration process (GRIFFIN; HAUSER, 1996; LEENDERS; WIERENGA, 2002; GONZALEZ-ZAPATERO; GONZALEZ-BENITO; LANNELONGUE, 2016). These mechanisms can be analyzed according to organizational point of views, resource and integration tools (Figure 1).

\subsection{Perspective of integration tools}

The formal management of the integration process according to Griffin and Hauser (1996) and Leenders and Wierenga (2002) include tools that can be used to support the realization of PDP activities, such as Quality Function Deployment (QFD), Stage-Gates and FMEA (Failure Mode and Effect Analysis). Stage Gate, for example, consists of a system or process responsible for the efficient and effective conduction of new product designs from conception to launch, and is based on a set of phases and decision points (COOPER, 2008). The FMEA can be applied to all phases of the product life cycle: System FMEA, Design FMEA, Process FMEA and Service FMEA (STAMATIS, 2005; WÜRTENBERGER et al., 2014). 


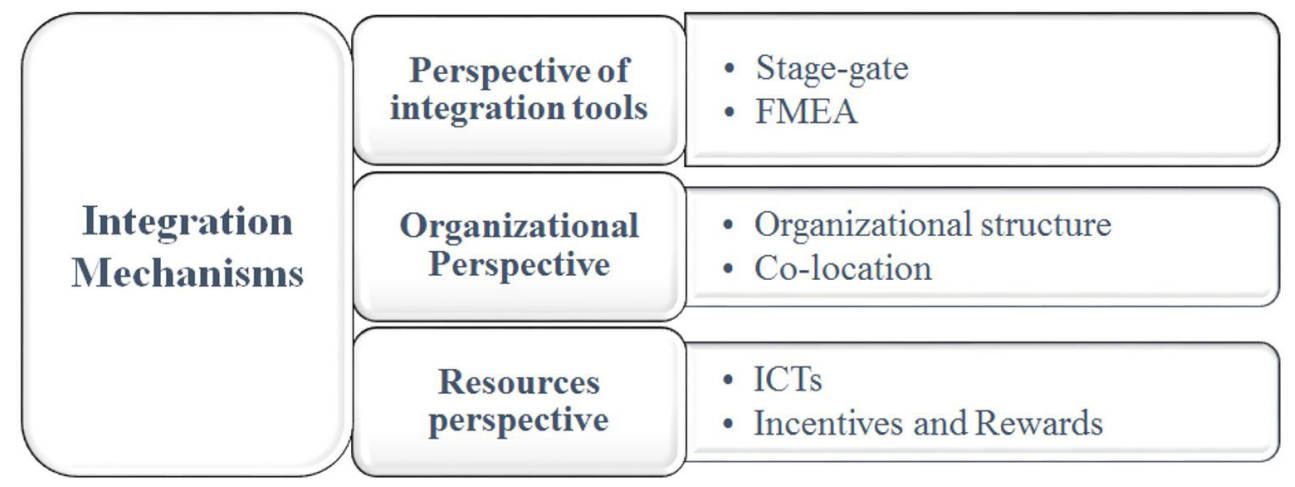

Figure 1. Mechanisms for integration in relation to organizational perspectives, resources and tools. Source: Authors.

\subsection{Organizational perspective}

Organizational integration mechanisms refer to the formal arrangement of functions in an organization such as the organizational structure and the co- location.

The organizational structure most conducive to integration is the multifunctional team, that is, a team made up of representatives from different functions and even areas outside the company, such as customers and suppliers, which often help to avoid problems related to quality, and also reduce and improve process efficiency (LEENDERS; WIERENGA, 2002; MINGUELA-RATA; ARIAS-ARANDA, 2009; HUO; ZHAO; LAI, 2014). Multifunctional teams encourage the exchange of information, provide and encourage cooperation, providing a forum in which conflicts are resolved without the intervention of senior management (GRIFFIN; HAUSER, 1996).

Co-localization during product development represents the union of people from different departments in the same physical location and seems to be a viable strategy to improve departmental performance and satisfaction, as the collaborative mechanisms are face-to-face, personal and more informal nature. In addition, co-location fosters interpersonal interaction, promotes the exchange of ideas between departments, and leads to better problem solving and performance results (KAHN, 1997; GRAY; SIEMSEN; VASUDEVA, 2015).

\subsection{Overview of resources}

Collaborative team processes can be enhanced through computer mediated communication technologies such as e-mail, video conferencing, intranet, and software. Information Technology (IT) artifacts - for example, e-mail, word processing and spreadsheet software, shared files, desktop tools - used throughout the process of developing new products, improve and accelerate the sending and receiving of information in addition to solving problems such as loss of time, resources, product quality, deadline through online collaboration with other team members, allowing integration among the various departments in real time, making the interaction more effective, because it makes the team available to collaborate and communicate from anywhere at any time (BANKER; BARDHAN; ASDEMIR, 2006; TSENG; ABDALLA; SHEHAB, 2006; REID et al., 2016).

These capabilities, in addition to facilitating interfunctional integration, enable project teams to reduce or eliminate delay times and improve the iteration of development processes so that quality problems are previously detected in the project lifecycle. These improvements are associated with significant reductions in product design cycle times and development costs (BANKER; BARDHAN; ASDEMIR, 2006), in addition to facilitating and eliminating communication barriers in the organization (DIETRICH et al., 2010).

Incentives and rewards play an important role in stimulating specific behaviors within organizations. Linking the compensation system to a common result, such as new product success or loyalty to the team rather than loyalty to the role, could promote greater coordination (GRIFFIN; HAUSER, 1996).

\subsection{Using FMEAs}

The FMEA contains several steps that must be performed and the principles of the tool are the same irrespective of the type of FMEA. There is no standard procedure for executing the FMEAs, however, many examples in the literature state that there should be a selection of a team, defined according to the nature of each project, noting that it can not be done individually (TENG; HO, 1996; STAMATIS, 2003; GUERRERO; BRADLEY, 2012; CABANES et al., 2016). The use of a simple methodology (spreadsheets), the reuse of knowledge (using analyzes of documented problems previously identified as input to new product development projects by analyzing reports and lessons learned in 
verification and validation phases) (CHAO; ISHII, 2007; ZHENG; LIU; MCMAHON, 2010; LODGAARD et al., 2011) are strong points in conducting FMEA and lead to knowledge sharing through joint analysis as well as providing a visual and easy-to-understand overview of the issues that need to be addressed (LODGAARD et al., 2011).

The FMEA can be used to coordinate a development group that is dispersed across continents, time zones and organizations so that the incidence of interface failures can be reduced as it is considered a mechanism that coordinates development groups and shares project information of product (GUERRERO; BRADLEY, 2012), thus configuring an integration mechanism. However, the difficulties encountered during FMEAs are associated with the interrelationships among various modes of failure due to communication (such as inappropriate information) and execution errors such as human errors (sometimes people do not complete a task, and sometimes they incorrectly complete it) inadequate information, inaccurate, incomplete or incorrect analysis (CHIN; CHAN; YANG, 2007; CHAO; ISHII, 2007; GUERRERO; BRADLEY, 2012) which can result in project failures.

Thus, the interdependent activities between PD and Quality Engineering and the DFMEA tool were analyzed as practices of interfunctional integration between PD and Quality Engineering (Figure 2). Practices are understood as activities, techniques, methods and tools used to achieve an outcome (KAHN et al., 2012), in this case, communication and collaboration between the departments concerned.

Different ways of understanding circumstances, personalities, languages, and organizational issues are conflicting elements that become barriers to integration. Thus, for greater coordination, the occurrence of interfunctional integration can be aided by different mechanisms, which can be analyzed from the organizational points of view, resources and tools for integration.

The Failure Modes and Effects Analysis (FMEAs), which aims to optimize product quality and reduce defects during development, is one of the main tools of Quality Engineering. In addition, the FMEAs are carried out by a multifunctional team and the interaction and collaboration among the members are fundamental to guarantee the quality of the products from the early stages of development, causing quality problems of the later stages to be reduced or even eliminated.

\section{Research method}

Field research was conducted through a case study, following the guidelines in the literature (YIN, 1989; VOSS et al., 2002). The justification is due to several aspects of the research, such as the importance of the context, that is, a large company with a Consolidated and Structured Product Development Process and Quality Management, in addition to Quality Management System certification, nature

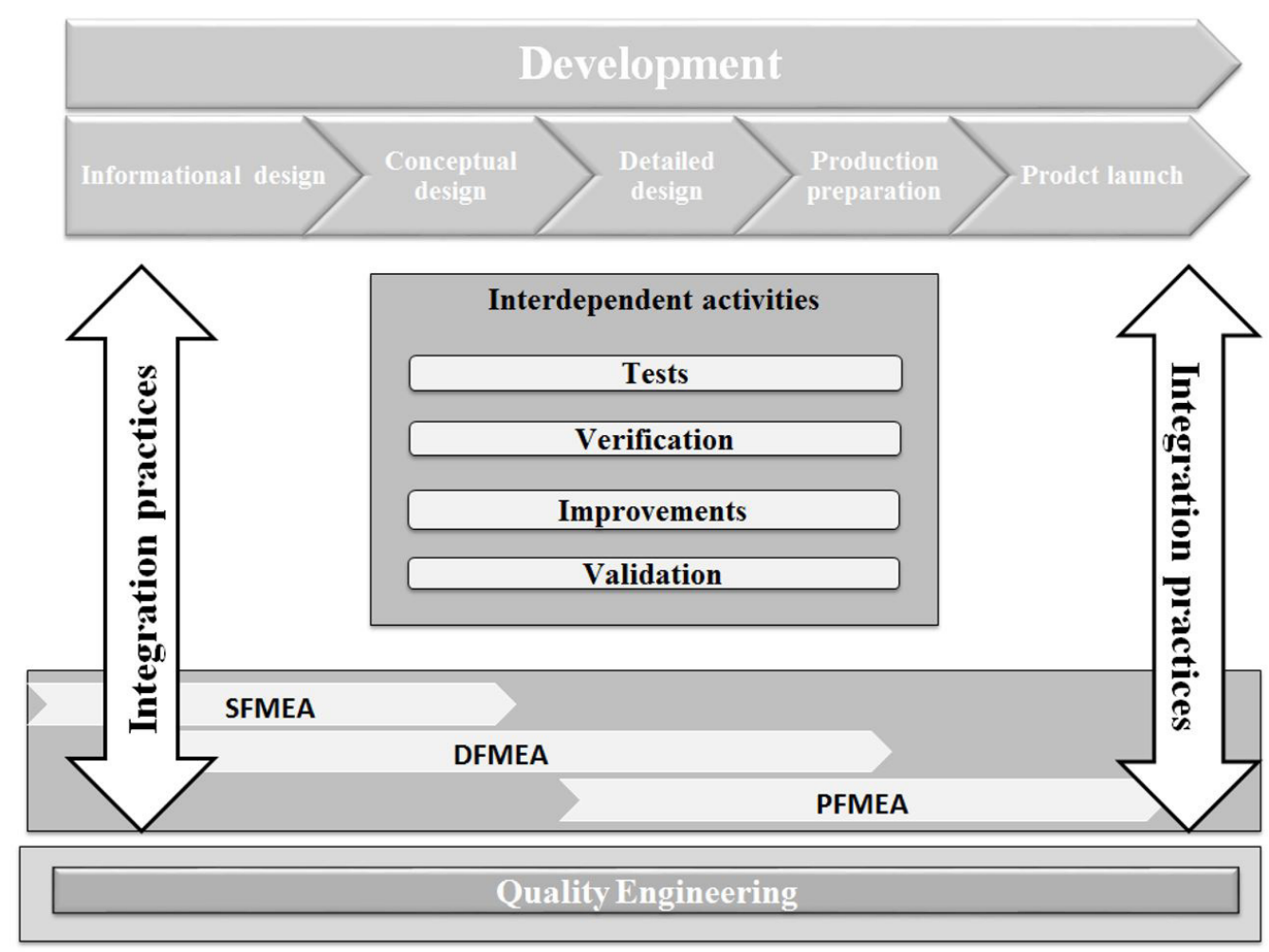

Figure 2. Integration between PD and Quality Engineering. Source: Authors. 
of the variables, predominantly of a qualitative nature, and the data collection and analysis approach, delimited in two cases which main criterion of choice was co-location between PD departments and Quality Engineering, that is, the physical distance between both in which one case is characterized by locating the departments in the same place and the other, not. These choices were made to observe in the real environment the practices used in the integration among the functions when the DFMEA is executed in these circumstances.

In both cases, the instruments of data collection were semi-structured interviews conducted with those responsible for the departments of Quality Engineering and Product Engineering (PE). Those responsible for managing product development projects, that is, company project leaders belong to the EP department. Thus, in company A, four interviews were conducted: director and quality supervisor, project leader and EP manager. In company B, the QE and PE managers were interviewed.

The questionnaire was developed in order to evaluate the interviewees' perceptions regarding the integration practices adopted by both departments from the perspective of integration, and more specifically, to identify the practices and techniques adopted in the implementation of the DFMEA in order to understand those that improve and contribute to the communication and collaboration of the QE in PD.

\section{Discussion}

In this topic the case study is presented. The first part is intended to present selected companies and their integration practices during the development of product phases, under the responsibility of the Product Engineering Department. Next, the communication and collaboration practices are exposed during the execution of a DFMEA in order to show how this tool contributes to the integration between PD and QE. The observations obtained in each case were grouped in Table 1.

\subsection{Case A}

Company A is a multinational company that operates in the consumer goods market. In Brazil, the organization has three manufacturing units and around 7,000 employees. The development process is similar to the traditional reference models in the literature of $\mathrm{PD}$, organized in macrophases, phases and gates, has three project leaders and the formation of the development team occurs according to the necessity of the activities to be carried out in the projects and the availability of the staff of each department.

The PE and QE departments are located in different cities and states, that is, they are not co-located and the company's QE performs activities in the development of products directly or indirectly cooperating with the EP, such as: elaboration of the quality plan (DFMEA development); average estimate of failures that the product will present in the field, based on history of other projects and experience of the QE department people involved; audits and evaluation of suppliers; approval of new items (the PE performs the specifications and the QE performs the tests); test methods (exhaustive tests in several stages - prototyping stage, test stage in definitive pieces, stage of tests in the process); evaluation of conformation and validation of products and manufacturing processes; inspections on raw materials and products, among others.

Table 1. General practices of integration between QE and PD of cases.

\begin{tabular}{|c|c|c|c|}
\hline \multicolumn{2}{|c|}{ Integration practices } & Case A & Case B \\
\hline & Organizational structure & Autonomous teams & Teams with heavyweight manager \\
\hline $\begin{array}{l}\text { Organizational } \\
\text { Perspective }\end{array}$ & $\begin{array}{c}\text { Co-location and physical } \\
\text { proximity }\end{array}$ & $\begin{array}{l}\text { Departments located in different cities and } \\
\text { states. Physical proximity is used when } \\
\text { they cannot solve issues by means of ICTs, } \\
\text { especially in the development of prototypes, } \\
\text { pilot batch manufacturing and problem } \\
\text { solving. }\end{array}$ & $\begin{array}{l}\text { There are, the departments are located in } \\
\text { the same building }\end{array}$ \\
\hline \multirow[b]{2}{*}{$\begin{array}{l}\text { Resources } \\
\text { perspective }\end{array}$} & Incentives and Rewards & $\begin{array}{l}\text { Profit sharing and rewards (RWP) through a } \\
\text { performance indicator associated with product } \\
\text { failures in the field. }\end{array}$ & $\begin{array}{l}\text { Profit sharing and rewards (RWP) } \\
\text { through a performance indicator } \\
\text { associated with non-quality costs. }\end{array}$ \\
\hline & ICTs & $\begin{array}{l}\text { Use of CAD, E-mail, Phone calls, Cloud } \\
\text { file sharing, Skype, video conferencing, } \\
\text { WhatsApp, Shared database (company's own } \\
\text { software) } \\
\end{array}$ & $\begin{array}{l}\text { Use of CAD, E-mail, Phone calls, } \\
\text { Videoconference, WhatsAppDatabase } \\
\text { (company's own software) }\end{array}$ \\
\hline \multirow[b]{2}{*}{$\begin{array}{l}\text { Perspective of } \\
\text { integration tools }\end{array}$} & DFMEA & Meetings of analysis through videoconference & Face-to-face meetings \\
\hline & Stage-Gates & $\begin{array}{l}\text { Evaluation meetings at the end of the PD } \\
\text { phases through videoconference involving } \\
\text { only departmental managers and responsible } \\
\text { directors. }\end{array}$ & $\begin{array}{l}\text { Evaluation meetings at all stages of PD } \\
\text { through videoconference involving only } \\
\text { departmental managers and responsible } \\
\text { directors. }\end{array}$ \\
\hline
\end{tabular}

Source: Authors. 
At the end of each development phase, there are formal meetings (gates) that take place periodically and have the purpose of verifying and evaluating the progress of the project and reviewing the results set in order to solve, presume and discuss problems, validate the project and create an action plan for the next phase. Gates involve only the managers of several departments along with the directors of the company and the communication occurs through videoconference with screen sharing due to the question of the geographic distance of the involved ones, that are located even in different countries. The main topics are documented (minutes and reports) and later are made available in the company's management software, allowing the sharing of information to the others in each department.

The integration between PE and QE does not only occur in gates and corporate software. Prior to these formal meetings, the departments, according to the four interviewees of company A, develop joint activities and share information, even if located geographically distant. $\mathrm{PE}$ and $\mathrm{QE}$ managers communicate over the phone or via Skype on a weekly basis to exchange project progress information, best practice methodologies, and discuss purchase, testing, and review requests.

Depending on the complexity of the project, the company makes use of the co-location between PE and QE during the elaboration of the prototype or when they can not solve the problems through the ICTs. One reason for the face-to-face meeting may be the existence of great uncertainty in radical projects, since in incremental projects the information about the product is usually consolidated in the company. In the manufacturing of the pilot lots, not only the personnel of the PE, but all those involved in the development project, that is, the entire multifunctional development team, accompanies the manufacturing in person, each interacting and collaborating with its analysis according to specific criteria.

Company A uses a variety of resources to enhance interaction among stakeholders and understanding product-related issues by uploading photos from multiple perspectives, videos through WhatsApp, email, cloud file sharing, and CAD use to try to drill down as much as possible, to avoid staff displacement and minimize transport costs.

There is a performance indicator related to product failures in the field that has a maximum allowable value, making employees from senior management to the operational area to carry out joint and common goal, that is, focusing on product quality to ensure Profit Sharing (RWP). Moreover, in Brazil, especially, the interviewees evaluated that the integration between $\mathrm{PE}$ and $\mathrm{QE}$ is high compared to other units of the company abroad, because the two departments are overseen by the same vice president, fostering more interaction and collaboration for the same objectives and goals.

\subsection{Case $B$}

Company B is a multinational company in the capital goods market that produces components and systems associated with several industrial segments. In Brazil, it has six factories and each unit is responsible for producing one type of product segment. The interviews of the case study occurred in one of the company's business units, located in a country town in the state of São Paulo, belonging to the electric segment and has 200 employees. QE members who participate in the development team are always the same and the PE members depend on the project leader and the availability and personal ability.

In the early stages of development the integration of QE occurs mainly through supplier verification and validation activities and in the implementation of DFMEA. During the development of prototypes information sharing happens through standard procedures such as the PPAP (Product Part Approval Process). At this stage, the development of joint activities is more frequent in carrying out product verification and validation activities. However, the preparation of these records requires the collaboration and sharing of information through meetings, phone calls, e-mails with the various departments involved in the PD.

Even when the departments are co-located, the use of ICTs is quite frequent, that is, the information and results of each activity related to the PD are documented in shared folders in the cloud or in the company's own software, to which all the departments involved in the PD have access. However, the physical proximity between the PE and QE departments means that collaboration and communication between them, through informal meetings and informal conversations, occurs more often, especially when problems arise.

As in case A, in all stages of development, there are approval analyzes of the same, called gates which interaction also happens through videoconference and screen sharing, since not all people who participate in a gate are located in the same plant.

In addition to the gates, there are meetings that take place periodically, at least every two weeks between $\mathrm{PE}$ and $\mathrm{QE}$ to analyze the progress of the project, share information, discuss aspects related to product quality and the development process, such as efficacy of activities, problem analysis, and product enhancements. Unlike gates, in case B, these meetings are held face-to-face since both departments are located on the same floor and generally occur as the need and complexity of each project. When there is no relevant information to discuss, the meeting is postponed; however, questions or fundamental information 
may arise that it is preferable to discuss them more quickly, in anticipation of the meetings.

In case $\mathrm{B}$, there is also an index referring to the costs of non-quality which must remain within the limits desired for the employees to have Profit Sharing and Rewards of the company (RWP), causing everyone to worry about the quality of the product developed. Thus, the RWP causes members to develop joint activities and communicate more frequently in order to keep this index referring to the costs of non-quality as small as possible.

\subsection{DFMEA's role in integrating $P D$ and $Q E$}

The reason for starting the DFMEA is mainly due to the requirements of the company's own product development procedures, that is, its use is considered an inherent activity of the PD and not only a requirement of the client, since it is intended to ensure the quality of the product from the beginning of development, characterizing a strong point of its use according to arguments presented by Lodgaard et al. (2011).

The quest for product quality enables members to develop joint activities and share information and resources through a multifunctional team that primarily involves the departments of Product Engineering and Quality Engineering as reported in the cases, reinforcing that the DFMEA can't be performed individually, that is, it is a group decision, as suggested in the studies by Guerrero and Bradley (2012) and Cabanes et al. (2016). In case A, the $\mathrm{QE}$ is responsible for managing this tool and in $\mathrm{B}$, the PE.

A discrepancy between the cases is related to the interaction practices for the DFMEA. In case A, DFMEA meetings are held by videoconference, due to the physical distance between $\mathrm{PE}$ and $\mathrm{QE}$, and in case $\mathrm{B}$, the meetings are face-to-face, that is, they use co-location. In addition, there is a brainstorming technique, in which, in case A, the whole team is obliged to state their opinion, unlike case B, where each one of the team expresses itself when necessary. Also in case $\mathrm{B}$, since $\mathrm{PE}$ and $\mathrm{QE}$ are co-located, several other means to improve the execution of the DFMEA are used, such as using the parts and/or samples of the physical products at fault-finding meetings, to bring the DFMEA team to the location where there is production of the product and meet with different operators in order to discuss possible failures and not only with a representative of them in the formal meetings of DFMEA. These practices are consistent with those identified by Gray, Siemsen and Vasudeva (2015).

Inconsistent communication errors and information transfers as reported by Cabanes et al. (2016) and Renu et al. (2016) and failures in the quality of information during the DFMEA as Würtenberger et al. (2014) report, can influence the quality of the product. Therefore, there are different integration practices for the execution of the DFMEA that make the information more specific and detailed, improving the quality of the same, and can explain the fact that most of the problems related to quality in case B, not related to the projects, but to the manufacturing problems, corroborating with some authors of the area (CHAN; IP; ZHANG, 2012; JIANG et al., 2012; KOCH et al., 2013, MARINI et al., 2015; LUNDGREN; HEDLIND; KJELLBERG, 2015; WÜRTENBERGER et al., 2014).

In both cases, a standard tool used for interaction in the realization and records of the DFMEA are spreadsheets due to operational and economic viability. In addition, the terminology used to describe the items of analysis within the DFMEA study is standardized, which may explain why they used the DFMEA of similar products previously developed as a starting point for a new analysis in both cases, so the importance of using previous records for information sharing. When designing a new product with different specifications, knowledge about the risks of the product as well as the appropriate inspection procedures is still uncertain and is mainly based on the experience of the staff. According to Lodgaard et al. (2011), the analysis of existing reports and the experience of the people involved in the analyzes are considered as strengths in the execution of FMEAs.

In case A, during the DFMEA meetings items already analyzed in previous DFMEAs with low RPN are ignored, in other words, the new failure report assumes the same analysis of previous report failures for the new product. However, assuming the same analysis, according to the reports, may result in product failures in use, corroborating with Chao and Ishii (2007) and Cabanes et al. (2016). In case $\mathrm{B}$, when the development project is an incremental innovation without significant product changes, DFMEA meetings are not performed once the DFMEA reports of similar products are reused. Despite this, there have been no reports that this practice has affected the quality of the final product.

To assist in the determination of failures in both cases, the main methods reported were Fault Tree Analysis, Ishikawa Diagram and Pareto Analysis, because DFMEA has many challenges. The use of these methods has the objective of collaborating with the analyzes in order to eliminate or solve product failures, such as Teng and Ho (1996), Stamatis (2003) and Cabanes et al. (2016) proposed in their studies.

The correlation between the application of DFMEA and the reduction of cost indices and product failure rates in the market is not monitored, that is, there are no data or indices that help analyze this correlation in both cases. However, according to the interviewees of case A, there have been cases of development in which the DFMEA of previous products was reused and some analysis were disregarded due to the low RPN, observing a considerable increase in the customer complaint, that is, the product presented 
problems when placed on the market. Respondents, in both cases, believe that the number of prototypes is reduced when DFMEA is performed, which contributes to reducing development costs and deadlines.

It is possible to perform a comparative analysis of the cases with the theory about the practices and integration mechanisms used in the implementation of the DFMEA, observed in Table 2.

The analysis of Table 2 shows that for the execution of the DFMEA, there are practices of integration among the functional areas of the company such as meetings, informal conversations, e-mails, reports and work development together through a team composed by mainly members of $\mathrm{QE}$ and $\mathrm{PE}$, in the pursuit of a common goal: minimizing failures to improve quality. The combination of these communication activities and the development of joint activities between the departments shows that the use of DFMEA promotes inter-functional integration, especially between PE and QE, since QE is usually a department made up of experienced people with the necessary knowledge to carry out adequate quality assessments, according to the reports.

One point that can be evidenced in the cases is that, in addition to these practices, the use of resources such as RWP can be considered as a motivation for PE and QE integration by executing the DFMEA, since in both cases this mechanism links the system of compensation of the employees to the indices of failures of the new product in the market and the costs of not quality causing the members to work together to reach the objectives of the quality.

In addition, the fact that the departments of Quality Engineering and Product Development have the same manager (case A), also reveals a characteristic that contributes to the integration between both, since all the results, including the DFMEA analyzes, should be reported to that same manager, causing everyone to walk together for the same objectives and goals.

\section{Conclusions}

The results of field research are in agreement with the theory indicating a strong characteristic in the use of the DFMEA since it is not used as a requirement of the clients only, but because it is a fundamental tool in the decision making of product development, causing the involved members to act improvement of results through the elimination of failures. Thus, from an organizational point of view, the use of multifunctional teams with participation in quality assurance meetings in both cases is essential, promotes the communication and collaboration of the QE in PD. When co-location is used for interaction among members during the execution of the DFMEA, the analysis meetings are more dynamic due to the use of several means to improve the execution of the same as the autonomy to expose their point of view and displacement of people to area of production. The adoption of different practices during the meetings makes the information more specific

Table 2. Comparison between integration practices identified in the literature and those observed in the cases. Source: Authors.

\begin{tabular}{|c|c|c|}
\hline Integration & DFMEA (theory) & Cases \\
\hline \multirow{5}{*}{$\begin{array}{l}\text { Interaction } \\
\text { (Meetings, teams, phone calls, } \\
\text { e-mails, standard procedures, } \\
\text { memos and reports, fax) } \\
\text { Collaboration } \\
\text { (Common objective, mutual } \\
\text { understandings, informal } \\
\text { activities, shared resources, } \\
\text { common vision, group spirit) }\end{array}$} & $\begin{array}{l}\text { FMEAs are a group decision function (TENG; } \\
\text { HO, 1996; STAMATIS, 2003; GUERRERO; } \\
\text { BRADLEY, 2012; CABANES et al., 2016). }\end{array}$ & $\begin{array}{l}\text { In both cases the DFMEA team is formed, mainly by QE and } \\
\text { PE. The difference is in those responsible for performing the } \\
\text { same (case A to QE is responsible and in case B, the PE) and } \\
\text { integration mechanism (case A, face-to-face meetings and } \\
\text { case B, meetings by videoconference). }\end{array}$ \\
\hline & $\begin{array}{l}\text { Use of standard spreadsheet with predefined } \\
\text { columns is used to define risk areas (CHAO; } \\
\text { ISHII, 2007; AUTOMOTIVE..., 2008; } \\
\text { LODGAARD et al., 2011). }\end{array}$ & $\begin{array}{l}\text { The cases follow a standard procedure and the results of the } \\
\text { analyzes are recorded in Excel spreadsheets. The rules and } \\
\text { criteria for applying the DFMEA are well defined in manuals } \\
\text { and procedures. }\end{array}$ \\
\hline & $\begin{array}{l}\text { Reuse of existing FMEAs by analyzing } \\
\text { reports and lessons learned in verification } \\
\text { and validation phases (CHAO; ISHII, } \\
\text { 2007; ZHENG; LIU; MCMAHON, 2010; } \\
\text { LODGAARD et al., 2011) }\end{array}$ & $\begin{array}{l}\text { Use of company-owned software that saves reports of failures } \\
\text { previously performed on similar products. In incremental } \\
\text { projects, in case A, there are analysis meetings and when the } \\
\text { RPN is low, the analysis is ignored. In case B, there is only the } \\
\text { reuse of all analyzes in DFMEAs reports of similar products. }\end{array}$ \\
\hline & $\begin{array}{l}\text { The FMEA is a living document that needs } \\
\text { to be updated throughout the development } \\
\text { to achieve the desired improvement } \\
\text { (LODGAARD et al., 2011) }\end{array}$ & $\begin{array}{l}\text { DFMEA is updated whenever there is a change in the product } \\
\text { or process due to registered failures or customer complaints. }\end{array}$ \\
\hline & $\begin{array}{l}\text { Use of methods such as brainstorming, cause } \\
\text { and effect analysis (Ishikawa diagram), } \\
\text { simulation, other FMEA, etc. (TENG; HO, } \\
\text { 1996; STAMATIS, 2003; CABANES et al., } \\
\text { 2016) in the search of fault minimization. }\end{array}$ & $\begin{array}{l}\text { In both cases brainstorming is used. In case A, members are } \\
\text { required to position themselves. In case B, each participant } \\
\text { has the autonomy to state his point of view or not. The use } \\
\text { of auxiliary methods such as Fault Tree Analysis, Cause } \\
\text { and Effect Diagram, and Pareto Analysis were reported in } \\
\text { both cases. }\end{array}$ \\
\hline
\end{tabular}


and detailed, improving the quality of the same leading to the reduction of quality problems. It is noteworthy that the two companies in the case study use the physical proximity between PD and QE to improve the resolution of product quality problems.

When departments are co-located the dynamism of the review meetings as well as informal conversations make the problem solutions more easier. When departments are geographically distant, different communication practices such as e-mail, photos, and videos from various product perspectives should be used during DFMEA reviews. The interaction through ICT resources should be clear, concise so that there is a greater understanding of the parties involved in order to avoid staff displacement, considered to be often costly as communication failures generally reflect in rework and on a loss of time. In the written communication there is still an aggravating, because the sender may not be available to clarify the message when necessary.

In addition to the use of teams, the cases revealed that the RWP can be considered a mechanism that contributes to improve the communication and collaboration between $\mathrm{PD}$ and $\mathrm{QE}$ in the execution of the DFMEA. The practice of linking employee compensation to market failure rates and the costs of non-quality encourages the exchange of information among members during a DFMEA urging them to work together to achieve a common goal: product quality.

Another mechanism of integration between PD and QE during the DFMEA observed in one case (case A) and it is worth mentioning that the $\mathrm{PD}$ and $\mathrm{QE}$ departments are under the same supervision. The PD and QE departments are supervised by the same manager is a practice that provides information sharing, since the results of the analysis of failures, the activities developed should be reported to the same manager leading all in a single goal, in addition to align decisions between them.

The research was limited to the reports of people of strategic and tactical level of the areas studied and indicated by the companies. Future research could also collect reports of operational-level staff from companies, providing a broader view of the integration aspects of teams.

Another possibility of continuity of the research is the investigation with a greater number of companies through a survey, with a greater level of unfolding of the practices and mechanisms, allowing greater power of generalization and consistency of the conclusions. In addition, analysis of associations between the performance of the DFMEA, through the integration of the $\mathrm{QE}$ in the $\mathrm{PD}$, and the reduction of failure rates, cost indexes and number of prototypes can be performed through quantitative data.

The results of the cases are a stimulus for the companies to seek to improve the practices of integration between PD and QE, mainly, in the adoption of strategies of execution of the DFMEA, for the improvement of the quality of the products, from the recognition of the problems and limitations of communication and collaboration. The managerial implications are in the perception that the integration between these departments can be beneficial and specific mechanisms can be used to promote integration between these areas.

\section{References}

AUTOMOTIVE INDUSTRY ACTION GROUP - AIAG. Potential Failure Mode and Effects Analysis (FMEA): reference manual. 4th ed. USA: AIAG, 2008.

BADIRU, A. B. Quality insights: the DEJI model for quality design, evaluation, justification, and integration. International Journal of Quality Engineering and Technology, v. 4, n. 4, p. 369-378, 2014.

BANGHART, M.; BABSKI-REEVES, K.; BIAN, L. Human induced variability during failure mode effects analysis. In: ANNUAL RELIABILITY AND MAINTAINABILITY SYMPOSIUM, 2016, Tucson. Proceedings... United States: Institute of Electrical and Electronics Engineers Inc., 2016.

BANKER, R. D.; BARDHAN, I.; ASDEMIR, O. Understanding the impact of collaboration software on product design and development. Information Systems Research, v. 17, n. 4, p. 352-373, 2006.

CABANES, B. et al. From FMEA as a problem solving method to a design-oriented process: toward a design perspective of FMEA In: INTERNATIONAL DESIGN CONFERENCE, DESIGN, 14., 2016. Dubrovnik, Croatia. Proceedings... Dubrovnik: Design Society, 2016.

CHAN, S. L.; IP, W. H.; ZHANG, W. J. Integrating failure analysis and risk analysis with quality assurance in the design phase of medical product development. International Journal of Production Research, v. 50, n. 8, p. 2190-2203, 2012.

CHAO, L. P.; ISHII, K. Design process error proofing: failure modes and effects analysis of the design process. Journal of Mechanical Design, v. 129, n. 5, p. 491-501, 2007.

CHEN, H.; DAUGHERTY, P. J.; ROATH, A. S. Defining and operationalizing supply chain process integration. Journal of Business Logistics, v. 30, n. 1, p. 63-84, 2009.

CHIN, K.; CHAN, A.; YANG, J. Development of a fuzzy FMEA based product design system. International Journal of Advanced Manufacturing Technology, v. 36, n. 7-8, p. 633-649, 2007.

COOPER, R. G. Perspective: the Stage-Gate $₫$ idea-to-launch process - update, what's new, and nexgen systems. Journal of Product Innovation Management, v. 25, n. 3, p. 213-232, 2008. 
DIETRICH, P. et al. The dynamics of collaboration in multipartner projects. Project Management Journal, v. 41, n. 4, p. 59-78, 2010.

ERIKSSON, M.; MOTTE, D. An integrative design analysis process model with considerations from quality assurance. In: ICED'13, Seoul. INTERNATIONAL CONFERENCE ON ENGINEERING DESIGN - ICED'13 19., 2013, South Korea. Proceedings... South Korea: Design Society, 2013. v. 75 , p. $449-458$.

GONZALEZ-ZAPATERO, C.; GONZALEZ-BENITO, J.; LANNELONGUE, G. Antecedents of functional integration during new product development: The purchasingmarketing link. Industrial Marketing Management, v. 52, p. 47-59, 2016.

GRAY, J. V.; SIEMSEN, E.; VASUDEVA, G. Colocation still matters: conformance quality and the interdependence of R\&D and manufacturing in the pharmaceutical industry. Management Science, v. 61, n. 11, p. 2760-2781, 2015.

GRIFFIN, A.; HAUSER, J. R. Integrating R\&D and marketing: a review and analysis of the literature. Journal of Product Innovation Management, v. 13, n. 3, p. 191-215, 1996.

GUERRERO, H. H.; BRADLEY, J. R. Failure modes and effects analysis: an evaluation of group versus individual performance. Production and Operations Management, v. 22, n. 6, p. 1524-1539, 2012.

HUO, B.; ZHAO, X.; LAI, F. Suply chain quality integration: antecedents and consequences. IEEE Transactions on Engineering Management, v. 61, n. 1, p. 38-51, 2014.

JIANG, X. et al. Study on product lifecycle oriented product design quality control system. In: INTERNATIONAL ASIA CONFERENCE ON INDUSTRIAL ENGINEERING AND MANAGEMENT INNOVATION (IEMI2012), 2012, Berlin. Proceedings... Heidelberg: Springer, 2012. p. 793-803.

KAHN, K.; MCDONOUGH, E. F. An empirical study of the relationships among co-location, integration, performance, and satisfaction. Journal of Product Innovation Management, v. 14, n. 3, p.161-178, 1997.

KAHN, K. B. et al. An examination of new product development best practice. Journal of Product Innovation Management, v. 29, n. 2, p. 180-192, 2012.

KAHN, K. Interdepartmental integration: a definition with implications for product development performance. Journal of Product Innovation Management, v. 13, n. 2, p. 137-151, 1996.

$\mathrm{KOCH}$, J. et al. Cycle oriented quality management at the interface of product development and production planning. Product Lifecycle Management for Society, p. 491-499, 2013.
KURNIATI, N.; YEH, R.; LIN, J. Quality inspection and maintenance: the framework of interaction. Procedia Manufacturing, v. 4, p. 244-251, 2015.

KWON, Y. et al. Remote control of quality using ethernet vision and web-enabled robotic system. Concurrent Engineering, v. 14, n. 1, p. 35-42, 2006.

LEENDERS, M. A.; WIERENGA, B. The effectiveness of different mechanisms for integrating marketing and R\&D. Journal of Product Innovation Management, v. 19, n. 4, p. 305-317, 2002.

LODGAARD, E. et al. Failure mode and effects analysis in combination with the problem solving A3. In: INTERNATIONAL CONFERENCE ON ENGINEERING DESIGN: ICED 11, LYNGBY/COPENHAGEN, 18., 2011, Denmark, Proceedings... Copenhagen: ICED, 2011. v. 9, p. 71-79. $</$ conf $>$

LUNDGREN, M.; HEDLIND, M.; KJELLBERG, T. Modeldriven process planning and quality assurance. Procedia Cirp, v. 33, p. 209-214, 2015.

MARINI, C. D. et al. Product development using QFD, MCDM and the combination of these two methods. Iop Conference Series: Materials Science and Engineering, v. 114, p. 1-8, 2015.

MINGUELA-RATA, B.; ARIAS-ARANDA, D. New product performance through multifunctional teamwork: an analysis of the development process towards quality excellence. Total Quality Management \& Business Excellence, v. 20, n. 4, p. 381-392, 2009.

OLSON, E. M. et al. Patterns of cooperation during new product development among marketing, operations and R\&D: Implications for project performance. Journal of Product Innovation Management, v. 18, n. 4, p. 258-271, 2001.

PAGELL, M. Understanding the factors that enable and inihibit the integration of operations, purchasing and logistics. Journal of Operations Management, v. 22, p. 459-487, 2004.

REID, M. et al. The impact of the frequency of usage of IT artifacts on predevelopment performance in the NPD process. Information \& Management, v. 53, n. 4, p. 422434, 2016.

RENU, R. et al. A knowledge based FMEA to support identification and management of vehicle flexible component issues. Procedia Cirp, v. 44, p. 157-162, 2016.

SHAO, X-Y. et al. A web-enabled collaborative quality management system. Journal of Manufacturing Systems, v. 25, n. 2, p. 95-107, 2006.

SONG, X. The impact of cross-functional joint involvement across product development stages: an exploratory study. Journal of Product Innovation Management, v. 15, n. 4, p. 289-303, 1998. 
STAMATIS, D. H. Failure mode and effect analysis: from theory to execution. Second version. Milwaukee: AQS Quality Press, 2005.

TENG, S. H.; HO, S. Y. Failure mode and effects analysis: an integrated approach for product design and process control. International Journal of Quality and Reliability Management, v. 13, n. 5, p. 8-26, 1996.

TSENG, K. C.; ABDALLA, H.; SHEHAB, E. M. A web-based integrated design system: its aplications on conceptual design stage. International Journal of Advanced Manufacturing Technology, v. 35, n. 9-10, p. 1028-1040, 2006.

VOSS, C.; TSIKRIKTSIS, N.; FROHLICH, M. Case research in operations management. International Journal of
Operations \& Production Management, v. 22, n. 2, p. 195-219, 2002.

WÜRTENBERGER, J. et al. Application of the FMEA during the product development process - Dependencies between level of information and quality of result. In: INTERNATIONAL DESIGN CONFERENCE, DESIGN 2014, Dubrovnik - Croatia. Proceedings... Dubrovnik: Design Society, 2014. p. 417-426.

YIN, R. K. Case study research: design and methods. London, Sage, 1989.

ZHENG, L. Y.; LIU, Q.; MCMAHON, C. A. Integration of process FMEA with product and process design based on key characteristics. Advances in Intelligent and Soft Computing, p. 1673-1686, 2010. 